\title{
The Experimental Study of Concrete Beams Reinforced with Different Types of Bars Carrying Capacity
}

\author{
Andrey Benin ${ }^{1, a}$, Sergey Semenov ${ }^{1}$ and Bogdanova Ekaterina ${ }^{1}$ \\ ${ }^{1}$ Petersburg State Transport University, 190031, 9 Moskovsky pr., Saint Petersburg
}

\begin{abstract}
The results of experimental study on concrete beams reinforced with glass fiber reinforced plastic (GFRP) bars are presented and compared with steel reinforced concrete beams and beams reinforced with steel and GFRP bars together. Three series of reinforced beams were tested in the flexure. The experimental data are showed that possible area in which GFRP bar possesses potential to employ is secondary reinforcement in concrete structures.
\end{abstract}

\section{Introduction}

Fiber reinforced plastic (FRP) bars are widely used construction material in abroad. This type of a bar has been successfully used as reinforcement for road construction, in bridge decks and for concrete structures in severely aggressive environments. FRP bars have several advantages compared to steel reinforcement such as high strength, low weight, electromagnetic neutrality, resistance to corrosion and low cost. All of these advantages could lead to increased durability of concrete structures, and reduced maintenance costs.

A large-scale program on the application of FRP bars for concrete structures has been initiated in USSR: FRP bars have been used for construction without insulation crossmembers for power line supports, as a reinforcement for an electrolysis bath, for construction of a warehouse for fertilizers, in bridge decks [1, 2]. But all scientific developments were stopped in 1990, due to the high production cost of this construction material. That is why the use of FRP bars have been widely spread in abroad in comparison with Russia.

Today the use of FRP bars for concrete structures in Russia leads to the necessary of experimental and theoretical researches of structures reinforced with FRP bars in order to develop the national normative documents for the design and construction of concrete structures using FRP bars [3-8]. It may be worth noting that today a lot of experimental programs are carried out in Russian research laboratories and institutes to gain an insight into the behavior of concrete structures reinforced with FRP bars [915].

The Mechanical laboratory of Petersburg State Transport University with the collaboration of St. Petersburg State Polytechnical University conduct experimental and numerical investigation FRP bars bond behavior with concrete and FRP bars behavior in the flexure [16].

The aim of the current study is to experimentally investigate the flexural behavior of concrete beams reinforced with FRP bars and to compare of carrying capacity and deflection of beams reinforced with steel bars and beams with combined reinforcement

\section{Experimental program}

Three series of reinforced concrete beams were tested in four-point-flexure. The geometry of the beams, the diameter of reinforcement and loading regime were identical for all specimens.

Three series included beams reinforced with four steel bars A500 (12 mm diameter), beams with four glass fiber reinforced plastic (GFRP) bars ( the bar is made of E-glass fibers in a polyester matrix Epikote 828, using a pultrusion process) and beams with two steel and two GFRP bars. Geometry of the beams and reinforcement pattern are given in Table 1. The beams were made from a ready-mixed concrete B45. The beams were loaded by Instron machine model SATEC $1200 \mathrm{KN}$. Overall view of experimental setup is shown in Fig. 1, a).

\footnotetext{
${ }^{a}$ Corresponding author: benin.andrey@mail.ru
} 
a)

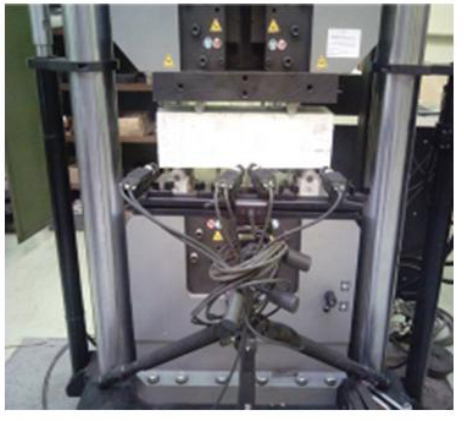

b)

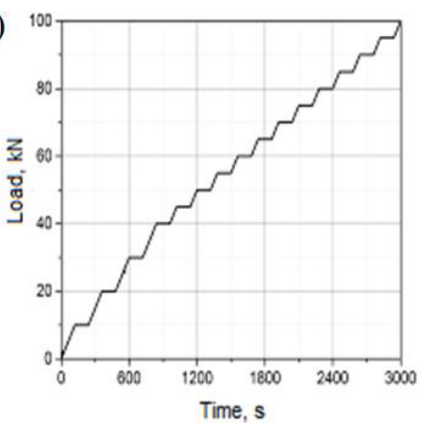

Figure 1. a) Overall view of experimental setup, b) Loading regime

Loading was applied stepped to the beams at a rate of $10 \mathrm{kN}$ per step with intermediate exposures until fracture as shown in Figure 1, b). The load was measured with the machine's load cell. The beam deflections were measured with a linear variable differential transformer (LVDT) at mid-span and under loading points. Strain fields were measured with two digital image correlation Vic3D systems on side of the beam painted by speckle pattern (Table 2).

\section{The experimental results}

The experimental dates are given in Table 1. Typical evolution of strain fields for experimental load at first crack, maximum load capacity and mode of failure of the concrete beams are presented in Table 1.

Table 1. The experimental dates

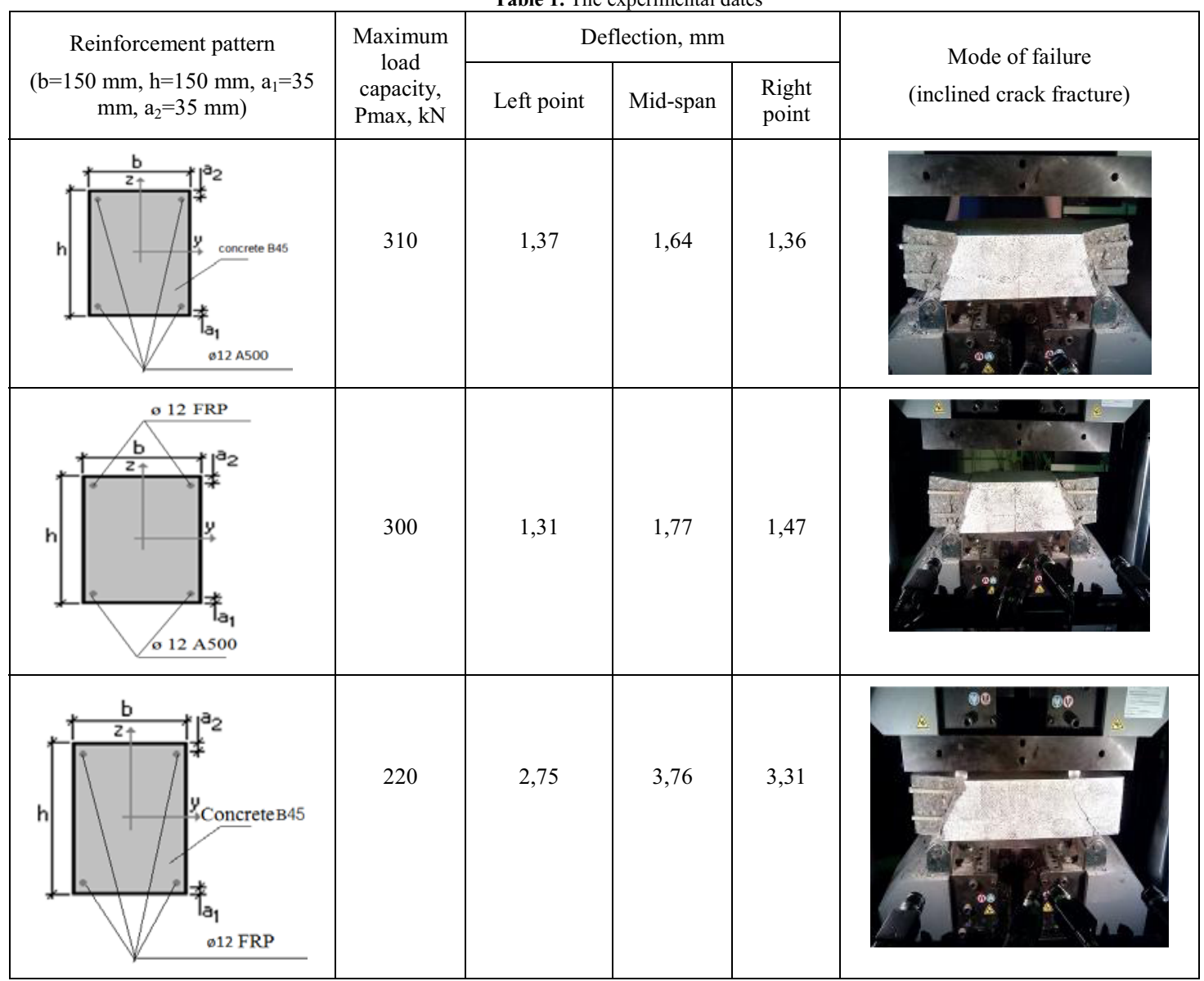


SPbWOSCE-2015

Table 2. Displacement and strain fields

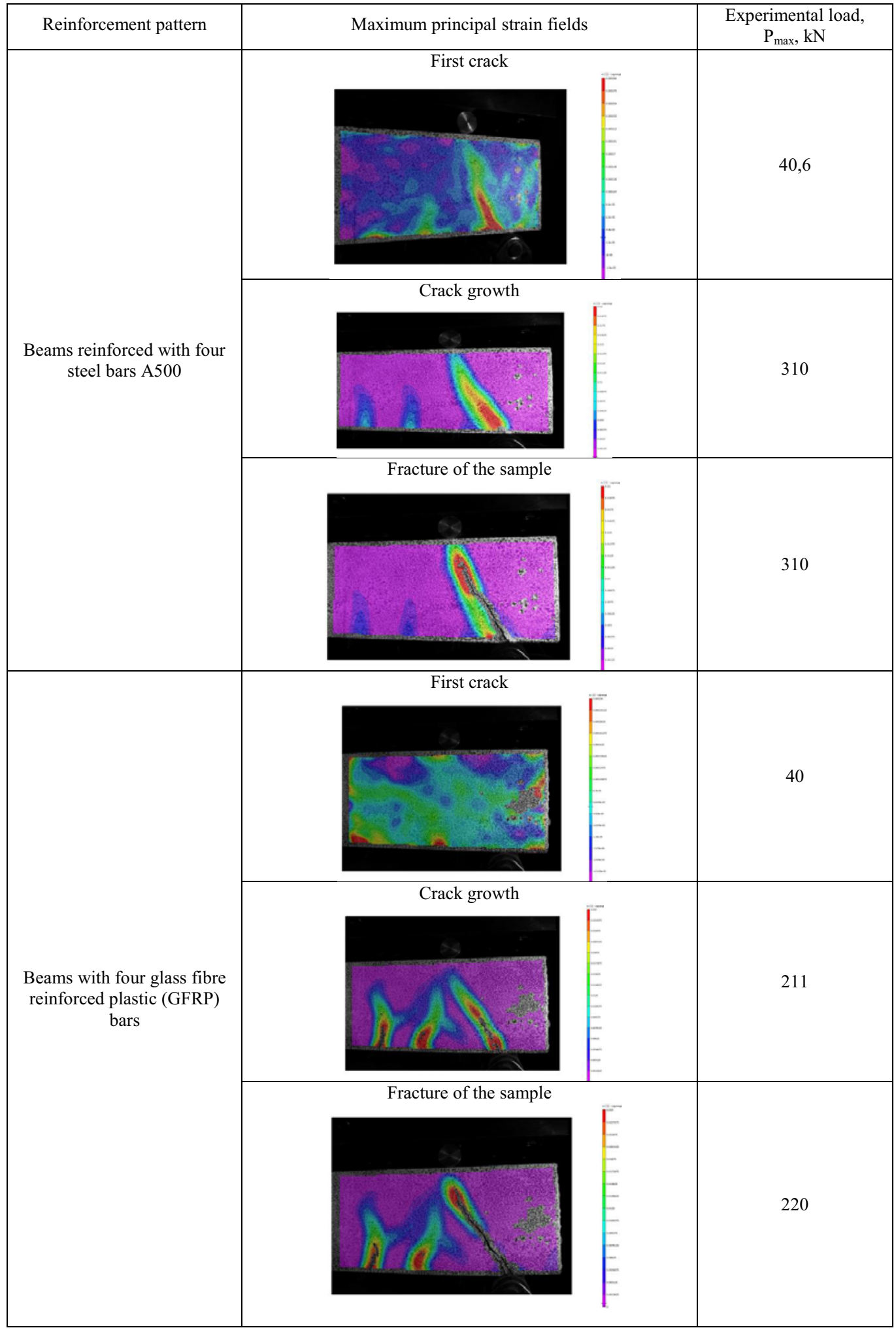




\section{MATEC Web of Conferences}

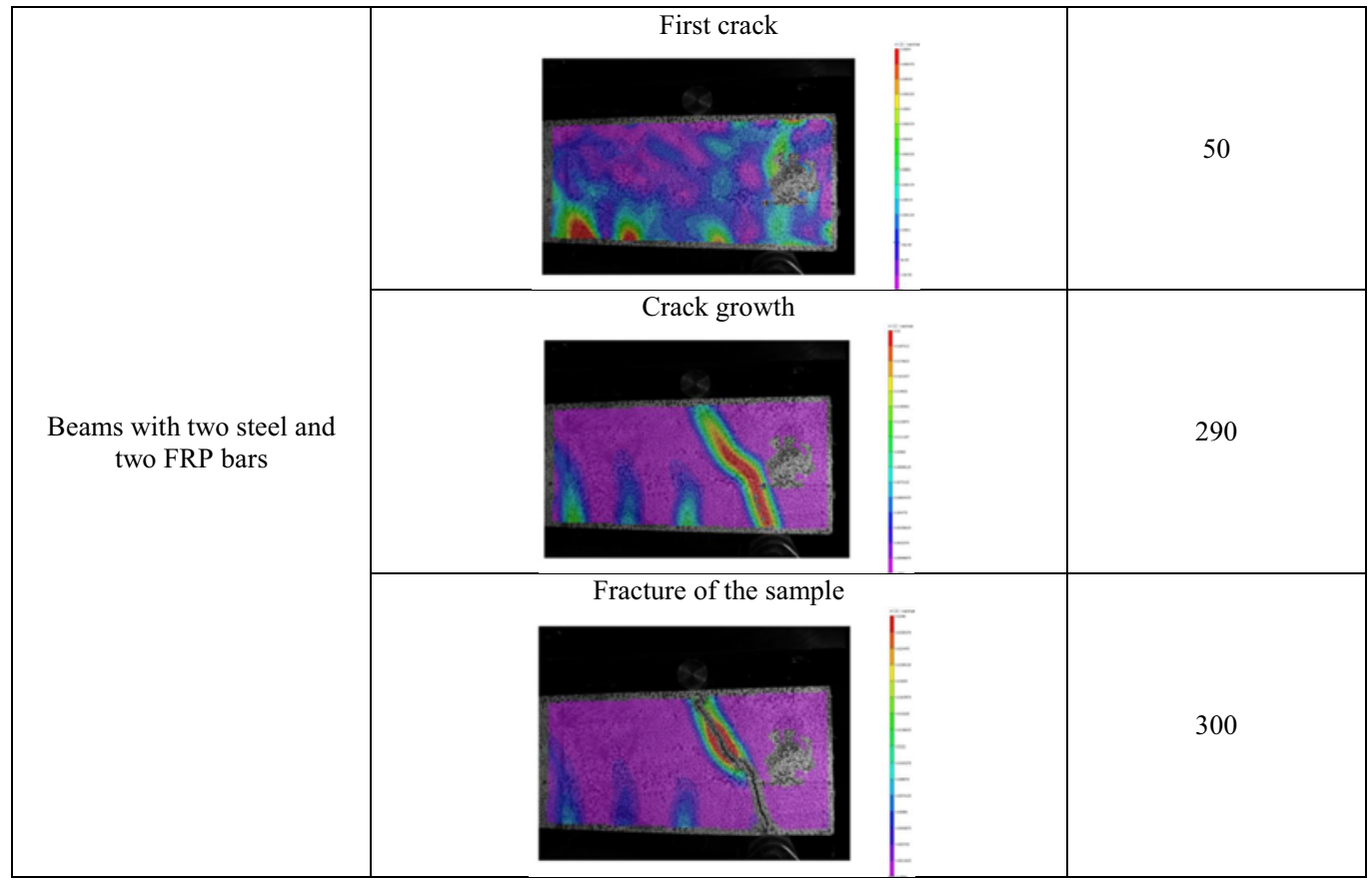

\section{Conclusions}

The experimental results have showed:

1. Crack initiation was started in bending zone. This cracks were stopped by the lower rebars. Later on inclined cracks was initiated and propagated from the bearing area. The main beam fracture reason is inclined cracks started from the bearing area.

2. Using of fiberglass rebars as main reinforcement leads to decreasing of the load capacity of reinforced concrete specimens in comparison with steel reinforced beam up to $29 \%$.

3. Concrete specimens reinforced by fiberglass rebars demonstrate high deformability in comparison with steel reinforced specimens which leads to appearance of meaningful deflections and as a consequence increasing of crack openings.

4. Using of hybrid reinforcement (fiberglass bars in compression zone and steel bars in tension zone) was practically not changed load capacity.

5. Thus, due to increased deformability of concrete elements reinforced with fiberglass rebars, the most appropriate area of using such type of rebars is secondary reinforcement, placed in nonleaded zones for decreasing amount of steel using for reinforcement.

\section{References}

1. V. Stepanova, A. Stepanov, E. Jirkov, Fibre reinforced plastic bars (2013)

2. ICI 440.1R-06 Guide for the Design and Construction of Structural Concrete Reinforced with FRP bars

3. V. Stepanova, Building materials, equipment, technologies of XXI century, 10, 12-14 (2014)

4. A. Benin, G. Bogdanova, S. Semenov, Applied Mechanics and Materials, 617, 215-220 (2014)

5. T. Zinnurov, A. Piskunov, L. Safiulina, O. Petropavlovskikh, D. Yakovlev, Internet-journal Science of science, 4, 1-12 (2015)

6. A. Benin, S. Semenov, Industrial and Civil Engineering, 9, 74-76 (2013).

7. V. Khozin, R. Gizatullin, A. Kuklin, A. Piskunov, News of the KSUAE, 1, 211-213 (2013)

8. Y. Klimov, O. Soldatenk, D. Oreshkin // URL: http://www.ekibar.org/files/frp_rebar_test_adhesion_concrete.pdf

9. S. Nikolskiy, N. Vatin, O. Pertseva (2015) Journal of Applied Engineering Science, 13 (1), $11-18$ (2015).

10. Z. Bonić, G.T. Curčć, M. Trivunić, N. Davidović, N. Vatin, (2015) Procedia Engineering, 117 (1), $424-435$ (2015)

11. V. Korsun, N. Vatin, A. Franchi, A. Korsun, P. Crespi, Mashtaler S. Procedia Engineering, 117 (1), $975-984$ (2015).

12. I. Garanzha, N. Vatin, Applied Mechanics and Materials, 633-634, 965-971 (2014)

13. N. Vatin, I. Pestryakov, S.Kiski, Z. Teplova, Applied Mechanics and Materials, 584-586, 1381-1387 (2014)

14. B. Kovačič, R. Kamnik, M. Premrov, N. Gubeljak, J. Predan, Z. Tišma, Strojniski Vestnik/Journal of Mechanical Engineering, 54 (5), 364-371 (2008)

15. B. Kovačič, R. Kamnik, International Journal for Engineering Modelling, 20 (1-4), 77-84 (2007)

16. E. Bogdanova, A. Benin, M. Belyaev, S. Semenov., A. Semenov, Collection of The XLII theoretical and practical conference with international participation «Week of Science in SPbSPU», 6-9 (2014) 